\title{
RELASI NASIONALISME ETNIK, NASIONALISME NEGARA DAN NASIONALISME KEWARGANEGARAAN DI PAPUA
}

\author{
Susanto T. Handoko, ${ }^{*}$ La Ode Hasirun
}

\author{
Program Studi Pendidikan Sejarah Fakultas Keguruan dan Ilmu Pendidikan \\ Universitas Cenderawasih, Jayapura - Indonesia \\ *Alamat korespondensi: susantoth15@gmail.com \\ DOI: https://doi.org/10.14710/jscl.v4i2.24269
}

Diterima/Received: 17 Juli 2019; Direvisi/ Revised: 8 Agustus 2019; Disetujui/ Accepted: 11 Desember 2019

\begin{abstract}
This article aims to discuss the dynamics of relations between ethnic nationalism, civic nationalism and state nationalism in the Land of Papua. The growth and development of Papuan ethnic nationalism since the integration of Papua into reform was caused by Indonesian state policies. Historical method is used in this research. The research approach is a qualitative approach to phenomenological research design. Strengthening Papuan ethnic nationalism due to the Central Government's (Jakarta) policies that were not fully accepted by indigenous Papuans. The Papuan people felt marginalized and discriminated against in the process of development in both the political, economic, social and cultural fields, especially during the New Order government. Papuan ethnic nationalism is characterized by demands for independence from the Indonesian state and instrumentalization of ethnicity for political purposes. Ethnic nationalism eventually shifts the civic and or state nationalism as part of the Indonesian state.
\end{abstract}

Keywords: Ethnic Nationalism; State Nationalism; Civic Nationalism; Papua.

\begin{abstract}
Abstrak
Artikel ini bertujuan untuk membahas dinamika relasi antara ethnic nasionalisme, civic nasionalisme dan state nasionalisme di Tanah Papua. Pertumbuhan dan perkembangan ethnic nasionalisme Papua sejak integrasi Papua hingga reformasi disebabkan oleh kebijakan negara Indonesia. Artikel ini disusun berdasarkan penelitian historis. Pendekatan penelitian adalah pendekatan kualitatif dengan desain penelitian fenomenologi. Menguatnya etnonasionalisme Papua karena kebijakan Pemerintah Pusat (Jakarta) yang tidak diterima sepenuhnya oleh orang asli Papua (OAP). Rakyat Papua merasa dimarginalisasi dan didiskriminasi dalam proses pembangunan baik bidang politik, ekonomi, sosial dan budaya khususnya di masa pemerintahan Orde Baru. Ethnic nasionalisme Papua ditandai oleh adanya tuntutan untuk merdeka dari negara Indonesia dan instrumentalisasi etnisitas untuk tujuan-tujuan politik. Ethnic nasionalisme akhirnya menggeser civic dan atau state nasionalisme sebagai bagian dari negara Indonesia.
\end{abstract}

Kata Kunci: Nasionalisme Etnik; Nasionalisme Negara, Nasionalisme Kewarganegaraan; Papua.

\section{PENDAHULUAN}

Keindonesiaan merupakan gagasan sekaligus karya yang belum selesai ( $a$ work in progress) atau bukanlah sesuatu barang jadi yang terbentuk secara alamiah (taken for granted), melainkan merupakan sebuah proses menjadi (becoming) atau proses nation building terus-menerus yang kalau tidak dirawat dan dipupuk akan pudar.
Keindonesiaan bukan realitas sudah jadi, tetapi proyek kekitaan, Indonesia in the making, bukan in waiting (Abdullah, 2001: 54; Jati, (ed.), 2017: 121; Kartodirdjo, 1994: 14; Pujiriyani, 2013: 154; Samego, 2008: 2; Suryadi, Hayat, Rustana \& Abduhzen, 2014: 48; Zuhdi, 2017: 38). Pudarnya semangat nasionalisme sudah terasa dewasa ini, ditandai dengan semakin kaburnya identitas Keindonesiaan (Amboro, 2015: 109). Setiap 
mendengar kata "Indonesia" atau mengatakan dirinya sebagai "orang Indonesia" nyaris tidak ada suasana esoteris yang muncul sebagai jati diri yang patut dibanggakan. Terkadang melintas dalam kenangan tentang kebinekaan, kepahlawanan, keramahan, kesalehan, kekayaan alam, dan Pancasila, tetapi ingatan itu segera didekonstruksi oleh beragam fakta yang menegasikannya, sehingga yang tersisa hanyalah kehampaan dan keputusasaan.

Keindonesiaan saat ini mendapat beragam tantangan baik faktor dari dalam maupun luar negeri (globalisasi). Tantangan tersebut antara lain berupa kesenjangan sosial ekonomi, ketidakadilan dalam pemerataan pembangunan antara Indonesia bagian Barat dan Timur, pelanggaran Hak Asasi Manusia (HAM), problem penegakan hukum, maraknya aksi radikalisme, terorisme, korupsi, tawuran antar kelompok di masyarakat (seperti antar kampung, antar supporter sepak bola dan antarpelajar/ mahasiswa). Beragam tantangan tersebut berkaitan erat dengan sejauh mana pemberdayaan warga negara oleh nagara.

Pemberdayaan warga negara oleh negara, hingga saat ini kehadiran negara di seluruh wilayah Indonesia masih diperdebatkan (Andriana (ed.), 2016: 43; Jati (ed.), 2017: 98; Narwaya., Faruk \& Budiawan, 2018: 54; Pamungkas, 2016b: 59; Pujiriyani, 2013: 154; Surakhmad, 2009: 181; Widjojo, 2009: xvii; Zuhdi, 2017:39). Relasi peran Ke-Indonesiaan adalah terkait erat dengan beragam upaya untuk menghadirkan hakikat keindonesiaan di seluruh Indonesia. Tujuan dasarnya adalah untuk menciptakan dan menyebarkan keadilan dan keadaban yang lebih konkret dan bermartabat di seluruh Indonesia. Substansi dari identitas nasional adalah jawaban atas pertanyaan tentang siapa sebagai orang dan bangsa Indonesia, serta apa yang membedakannya dengan yang bukan Indonesia. Masalah keindonesiaan adalah masalah proses nation buildingyang merupakan masalah seluruh warga negara Indonesia. Hal ini dilandasai bahwa nasionalisme Indonesia yang lahir pada awal abad ke-20 merupakan konstruksi etno-nasionalisme dari berbagai daerah di Nusantara.
Keindonesiaan di Papua menghadapi tantangan yang cukup berat sejak integrasi Papua (1963/1969) ke negara Indonesia hingga saat ini. Terdapat kesenjangan pemaknaan antara orang asli Papua (OAP) dan Indonesia tentang relasi Indonesia dan Papua. Dinamika relasi Indonesia dan Papua menampakkan "dua wajah" dominan, yakni Nasionalisme Papua (Papua Merdeka) dan Nasionalisme Indonesia (pro-Negara KEsatuan Republik Indonesia) (Aditjondro, 2000: 5; Larasati, 2014: 488; Meteray, 2012: 53; Kaisiepo, 1999: 167; Rahab, 2006: 3; Soedharto, 1995: 22; Widjojo (Ed.), 2009: 1). Beragam persoalan di Papua khususnya yang berkorelasi dengan Pemerintah Pusat termanifestasikan dalam empat aspek utama yang saling terkait yakni: (1) masalah marginalisasi dan efek diskriminatif terhadap orang Papua; (2) kegagalan pembangunan terutama bidang pendidikan, kesehatan, dan pemberdayaan ekonomi rakyat; (3) adanya kontradiksi sejarah dan konstruksi identitas politik antara Papua dan Jakarta, dan (4) pertanggungjawaban atas kekerasan negara di masa lalu (Orde Baru). Widjojo (ed.), (2009: 227) menyimpulkan sebagai berikut: "Jika persoalan-persoalan di Papua tersebut dipotret dalam perspektif ideologis, maka yang menjadi dasar dari semua permasalahan adalah persoalan relasi makna Ke-Indonesiaan dan Ke-Papua-an”. Oleh karena itu, nasionalisme di Papua dalam konteks civic nasionalisme dan state nasionalisme menghadapi tantangan dengan tumbuh dan berkembangnya ethnic nasionalisme.

Pertumbuhan dan perkembangan ethnic nasionalisme Papua sejak integrasi Papua dalam negara Indonesia disebabkan oleh kebijakan negara yang memarginalkan dan mendiskriminasi OAP dalam proses pembangunan di Papua. Khususnya masa Orde Baru, OAP merasa dirinya dimarginalisasi, didiskriminasi oleh negara dan kaum pendatang (non-Papua) dalam bentuk ketidakberdayaan dalam aktivitas/persaingan bidang ekonomi, sosial, budaya, dan politik. Kondisi tersebut diperparah oleh status Daerah Operasi Militer (DOM) oleh negara terhadap Papua. Akhirnya ada kecenderungan pelanggaran dan kekerasan oleh oknum atau aparat Tentara 
Nasional Indonesia (TNI) dan Polisi Republik Indonesia (POLRI) dalam menjaga ketertiban, keamanan dan kedaulatan negara di Papua. Nasionalisme etnik Papua ditandai oleh adanya tuntutan untuk merdeka dari Indonesia dan instrumentalisasi etnisitas untuk tujuan-tujuan politik. Nasionalisme etnik akhirnya menggeser nasionalisme kewarganegaraan dan atau negara sebagai bagian dari negara Indonesia.

\section{METODE}

Data dalam artikel ini diperoleh melalui studi pustaka dan kajian lapangan. Studi pustaka dilakukan dengan menelaah hasil penelitian sejenis yang telah dipublikasikan baik dalam buku dan jurnal. Kajian lapangan bertujuan untuk mengumpulkan data melalui observasi dan Focus Group Discussion (FGD). Observasi dilakukan dengan mengamati kondisi lingkungan sosial Papua (khususnya Kota Jayapura). Kota Jayapura ibarat "miniatur Indonesia", titik simpul bertemunya beragam etnis, ras, agama, budaya dan politik. FGD dilakukan dengan stakeholder di Papua (dosen, mahasiswa, guru, tokoh agama dan tokoh masyarakat/adat). Pendekatan penelitian yang peneliti gunakan adalah pendekatan kualitatif dengan desain penelitian fenomenologi. Desain penelitiaa fenomenologi sebagai asumsiasumsi dan tindakan-tindakan yang digunakan peneliti ketika bergerak dari paradigma atau desain (srategi) penelitian menuju tahap pengumpulan data empiris di lapangan. Dengan desain fenomenologi peneliti berusaha memahami makna dari berbagai fenomena (fokus kepada fenomena), peristiwa dan interaksi manusia dalam situasi yang khusus. Tekanannya diarahkan pada berbagai aspek subyektif dari perilaku individu-individu (Creswell, 2014: 20; Jailani, 2013: 42; Rachman, 2015: 167). Dengan cara ini akan dapat dipahami makna dari berbagai peristiwa dalam kehidupan. Melalui strategi fenomenologi perhatian diarahkan pada interaksi sosial di antara warga masyarakat Papua baik secara vertikal maupun horisontal. Pendekatan penelitian fenomenologi merupakan pandangan berfikir yang menekankan pada pengalaman-pengalaman manusia dan bagaimana manusia menginterpretasikan pengalamannya. Ditinjau dari hakikat pengalaman manusia dipahami bahwa setiap orang akan melihat realita yang berbeda pada situasi yang berbeda dan waktu yang berbeda. Oleh karena itu, metode dalam fenomenologis ini menekankan kepada bagaimana seseorang memaknai pengalamannya (Hardiansyah, 2013: 228; Hasbiansyah, 2008: 163; Jailani, 2013: 41; Novianti \& Tripambudi, 2014: 119). Menarik untuk dikaji bagaimana relasi antara nasionalisme etnik, nasionalisme kewarganegaraan dan nasionalisme negara di Papua dari integrasi Papua ke Indonesia hingga reformasi.

\section{NASIONALISME ETNIK}

Papua memiliki keragaman suku bangsa berdasar Sensus Penduduk tahun 2000, suku bangsa di Papua berjumlah 312 yang masing-masing suku bangsa memiliki tradisi (kebiasaan), konsep agama (agama lokal), bahasa (253 bahasa yang digunakan sehari-hari), struktur sosial, dan kondisi geografis yang berbeda. Dari sisi kondisi geografisnya, ratusan suku bangsa yang beragam tersebut sebenarnya terbentuk oleh kondisi alamnya. Terdapat tiga wilayah geografis berbeda yang menentukan cara hidup masyarakat Papua. Pertama, daerah pantai yang dihuni nelayan dan pelaut. Kedua, daerah pegunungan yang padat penduduk dengan iklim yang sehat yang dihuni petani. Ketiga, daerah tanah rawa yang sangat jarang penduduknya. Ditambah lagi dengan adanya sekitar 100 kelompok suku bangsa nonPapua. Selain keragaman suku bangsa yang ada di Papua yang mencapai ratusan, ragam ras juga sangat menonjol. Perbedaan mendasar mengenai suku bangsa ini adalah ras Melanesia dan Austronesia. Melanesia adalah ras asli orang Papua, sementara Austronesia adalah ras pendatang.

Keragaman suku bangsa di Papua beserta sistem kebudayaannya bukan tanpa dinamika sehingga konflik adalah hal yang dianggap biasa, sebagai akibat perbedaan pandangan tentang sesuatu, atau akibat dari pengentalan kesadaran identitas kesukuan. Konflik sosial dipicu karena perbedaan suku bangsa, budaya, dan golongan atau kelompok. Konflik terjadi lebih karena 
permasalahan yang dianggap merugikan dan mengganggu bahkan melanggar aturan dan norma yang berlaku pada suku-suku bangsa yang ada. Misalnya, masalah perzinahan atau perselingkuhan, pembunuhan, kematian tidak wajar, dan rasa dendam yang mendalam. Beberapa hal tersebut merupakan penyebab perang antarsuku bangsa di daerah pedalaman Papua. Di samping itu, konflik internal antarsuku bangsa yang terjadi di masa lalu juga menjadi penyebab perang antarsuku bangsa dan kelompok. Suku-suku bangsa tertentu di Papua mempunyai tradisi perang sangat kuat. Konflik suku bangsa di Papua memiliki unsur etnonasionalisme dan masyarakat adat. Etnonasionalis, satuan etnik yang hidup dalam wilayah tertentu (Papua) dan ingin memisahkan diri dari negara (RI), dan masyarakat adat, hidup dalam wilayah tertentu dan menginginkan otonomi yang lebih besar dari negara yang memerintah untuk melindungi tanah adat.

Nasionalisme yang berkembang di Papua sejak integrasi ke NKRI tahun 1963/1969 hingga era reformasi menampakkan dua wajah yang dominan. Nasionalisme yang sejatinya hanya sentralistik di level nasional kemudian bergeser pada level lokal. Pergeseran hegemonik wacana nasionalisme ini terjadi akibat dari kondisi sosial politik yang berkembang di Papua. Pergeseran nasionalime ini menjadi masalah di tingkat nasional dan mengganggu keutuhan wilayah negara. Nasionalisme kemudian dinilai mendasari perlawanan bersenjata di Papua, yakni Organisasi Papua Merdeka (OPM). Perkembangan nasionalisme ini sebenarnya adalah suatu keniscayaan karena sebagai suatu imagined community, nasionalisme memiliki dinamika tersendiri. Berbeda etno-nasionalisme di daerah lain (seperti Aceh, Jawa, Kalimantan, Maluku, Padang dan Sulawesi) yang memiliki kontribusi dalam konstruksi nasionalisme Indonesia, maka etno-nasionalisme Papua tidak demikian.

Kealpaan negara Indonesia dalam memahami bekerjanya imajinasi kolektif (nasionalisme) tersebut berpotensi memperumit keadaan di Papua. Nasionalisme mempunyai makna beragam dan pemaknaan tersebut dimanfaatkan menurut sudut pandang dan kepentingan masing-masing pengusungnya. Hanya saja yang menjadikan nasionalisme tersebut memiliki signifikansi politik adalah karena watak ideologis yang melekat dalam imajinasi kolektif tersebut. Perkembangan internalisasi nasionalisme ini yang kemudian menghasilkan tumbuhnya chauvinism orang Papua terhadap dirinya, dan menutup diri dari keberadaan Indonesia.

Menguatnya etno-nasionalisme Papua karena kebijakan Pemerintah Pusat (Jakarta) yang tidak diterima sepenuhnya oleh rakyat Papua. Rakyat Papua merasa dimarginalisasi dan didiskriminasi dalam proses pembangunan baik bidang politik, ekonomi, sosial dan budaya khususnya di masa pemerintahan Orde Baru. Kebijakan Pemerintah Pusat tersebut didukung oleh kehadiran aparat militer (TNI) dan Polri yang cukup dominan dalam konteks Papua sebagai Daerah Operasi Militer (DOM). Aparat TNI dan Polri dalam menjalankan tugas negara disinyalir terjadi pelanggaran HAM di Papua. Oleh karena itu, dalam memori kolektif rakyat Papua adalah terjadinya beberapa tindak kekerasan dan kekejaman oleh oknum aparat keamanan negara. Selanjutnya, kehadiran kaum pendatang (nonPapua) juga dirasakan sebagai bentuk persaingan antara OAP dengan non Papua dalam berbagai bidang kehidupan seperti ekonomi dan agama. Eksistensi kaum pendatang cukup mendominasi perekonomian di Papua karena keunggulan Sumber Daya Manusia (SDM) dan modal dibandingkan OAP. Sementara faktor agama (Islam) yaitu mayoritas kaum pendatang adalah beragama Islam, sedangkan Tanah Papua dikenal sebagai Tanah Kristen (mayoritas beragama Kristen). Program transmigrasi oleh Pemerintah Pusat juga disinyalir sebagai bentuk kolonisasi dan penyiaran agama (Islam) di Papua.

Kasus Papua dalam politik identitas lebih terkait dengan masalah etnisitas, agama, ideologi, dan kepentingan-kepentingan lokal yang diwakili pada umumnya oleh para elite dengan artikulasinya masing-masing. OPM dapat dipandang sebagai salah satu wujud dari reaksi kegelisahan politik identitas itu atas ketidaksetaraan politik sentralistis Pemerintah Pusat (Jakarta). Isu-isu tentang keadilan dan 
pembangunan daerah menjadi sangat sentral dalam wacana politik, dan sangat sensitif jika bersinggungan dengan politik identitas. Identitas dalam hal ini mampu merusak nasionalisme itu sendiri sekaligus juga mampu membangkitkan etno-nasionalisme yang menjadi dasar perlawanan baru terhadap negara.

Identitas Ke-Papua-an terus memosisikan diri sebagai ideologi yang cenderung bertentangan dengan logika identitas yang dibentuk oleh negara. Identitas menjadi instrumen penting yang membentuk sebuah rasa bersama yang hadir untuk melepaskan diri dari Pemerintah Pusat (Jakarta), karena Indonesia dianggap sebagai penjajah. Oleh karena itu, di Papua, identitas menjadi hal yang paling dipertahankan oleh masyarakatnya.

\section{NASIONALISME KEWARGANEGARAAN}

Nasionalisme kewarganegaraan (nasionalisme sipil) adalah nasionalisme yang menempatkan/ memosisikan negara dalam memperoleh kebenaran politik dari partisipasi aktif rakyatnya. Keanggotaan suatu bangsa dalam hal ini bersifat sukarela. Negara Indonesia lahir pada 1945 akibat dari penjajahan Belanda yang kemudian dihadapkan pada masalah persatuan. Indonesia sebagai negara kepulauan, yang bapak pendiri gerakan nasionalisnya berasal dari pusat (Jakarta). Berdasar keanekaragaman geografis ini, Sukarno menggunakan konsep Indonesia Raya sebagai konsep nasionalisme Indonesia, yang ditujukan untuk perumusan masyarakat Indonesia. Indonesia sebagai negara kepulauan, maka penyatuan (integrasi) merupakan instrumen penting yang dapat digunakan untuk menghadapi keragaman tersebut. Nasionalisme Indonesia secara ideologis dimanifestasikan dalam Pancasila (lima prinsip negara). Lima prinsip tersebut adalah kepercayaan kepada Tuhan, humanitarianisme, nasionalisme, demokrasi, dan keadilan sosial. Hal ini dipostulasikan sebagai nilai bersama yang mendukung masyarakat toleran, majemuk, dan religius.

Nasionalisme kewarganegaraan di Papua adalah bentuk kesadaran warga dalam keberagaman Indonesia baik etnis, ras, agama, dan budaya. Warga sadar bahwa hidup di negara yang beragam dituntut adanya toleransi dalam interaksi sosial. Papua sebagai "miniatur" Indonesia maka toleransi antarwarga masyarakat adalah keniscayaan dalam mewujudkan Papua sebagai tanah damai. Salah satu contoh nasionalisme kewarganegaraan di Papua tampak dalam toleransi antarumat beragama, khususnya di wilayah Fakfak dan Kaimana dengan semboyan "Satu Tungku Tiga Batu”. Makna dari semboyan tersebut bahwa dalam satu rumah (keluarga) terdapat tiga agama yang dianut di antara para anggota keluarga (ayah, ibu dan anak). Pada dasarnya nasionalisme kewarganegaraan di Papua berkembang cukup baik dengan adanya toleransi antar umat beragama, antaretnis, antarbudaya, dan lainya pada diri warga negara yang tinggal di Tanah Papua. Munculnya gesekan, konflik dan lainnya adalah keniscayaan pada daerah dan atau negara multikultur, seperti Papua dan atau Indonesia. Prinsipnya adalah bagaimana pemerintah Pusat dan Daerah beserta semua elemen masyarakat mengelola modal multikultur dengan bijak, dengan jalan penegakan hukum dan penciptaan keadilan di tengah masyarakat. Oleh karena itu, dalam negara yang multikultur penting untuk ditanamkan kepada setiap warga negara akan pemahaman, sikap dan perilaku terhadap penghormatan dan penghargaan segala bentuk keberagaman dan perbedaan tersebut (Mahfud, 2014: 135). Hal itu dilandasi oleh multikulturalisme yang menjadi semangat dari pembentukan negara bangsa Indonesia. Multikulturalisme menjadi dasar bagi terbentuknya nasionalisme kewarganegaraan suatu bangsa.

\section{NASIONALISME NEGARA}

Nasionalisme negara merupakan variasi nasionalisme kewarganegaraan yang sering dikombinasikan dengan nasionalisme etnis. Dalam nasionalisme negara, bangsa adalah suatu komunitas yang memberikan kontribusi terhadap pemeliharaan dan kekuatan negara. Unsur terpenting dari nasionalisme negara adalah kewilayahan dan regulasi negara. Negara memiliki wilayah yang berdaulat dan mengatur warganya 
berdasar serangkaian kebijakan atau perundangundangan.

Nasionalisme negara diterapkan di Papua dalam konteks berbagai kebijakan Pemerintah Pusat baik aspek ekonomi, sosial, budaya, politik, dan pertahanan keamanan. Kebijakan negara tersebut bersifat sentralistik tanpa memperhatikan kondisi sosial dan budaya lokal (Papua). Papua dipaksa untuk menerima dan melaksanakan kebijakan Pusat, tanpa kuasa untuk menolaknya. Politik penyeragaman tersebut tentunya ada yang tidak sesuai atau bertentangan dengan kondisi lokal Papua. Sebagai contoh program penggantian "koteka" dengan pakaian nasional, pemberlakuan DOM di Papua, penggantian konsumsi sagu dengan beras, dan program transmigrasi. Kebijakan tersebut sering memarginalkan dan mendiskriminasi penduduk lokal serta ketergantungan penduduk lokal akan produkproduk dari luar Papua.

\section{RELASI NASIONALISME ETNIK, KEWAR- GANEGARAAN, DAN NEGARA DI PAPUA}

Kontestasi wacana dominan antara negara nasionalisme dan nasionalisme etnik di Papua adalah persoalan sejarah integrasi Papua ke wilayah negara Indonesia dan identitas politik orang Papua dalam konteks peralihan kekuasaan dari Belanda ke Indonesia dan Perang Dingin. Sebenarnya akar konflik Papua adalah perbedaan konstruksi nasionalisme Indonesia dan nasionalisme Papua. Narasi dominan (nasionalis Indonesia) berpandangan bahwa secara teritori Papua adalah bagian dari negara Indonesia, status politik sudah sah melalui Penentuan Pendapat Rakyat (Pepera) dan Resolusi PBB. Dalam konteks ini "integrasi" dimaknai sebagai pembebasan dari kolonialisme Belanda. Sebaliknya, narasi tandingan (nasionalis Papua) memandang bahwa orang Papua bukan bagian dari Indonesia karena perbedaan ras, Pepera dianggap tidak sah karena tidak merepresentasikan aspirasi rakyat Papua. Selain itu, dalam perspektif nasionalis Papua, Negara Papua Barat telah ada dan diproklamasikan sejak 1 Desember 1961.
Dalam konteks ini “integrasi” dimaknai sebagai kolonisasi Indonesia.

Perbedaaan tajam antara nasionalisme negara dan nasionalisme etnik mengakibatkan munculnya kekerasan politik dan pelanggaran HAM. Narasi dominan (nasionalis Indonesia) memaknai "kekerasan" sebagai cara untuk menjaga keutuhan negara Indonesia dan gagasan untuk memisahkan dari negara Indonesia ialah bertentangan dengan hukum. Negara direpresentasikan oleh militer (TNI) dan kepentingan negara ialah kepentingan militer dengan formulasi politik negara Indonesia. Sebaliknya, narasi tandingan (nasionalis Papua) memaknai "kekerasan" adalah pelanggaran (pelanggaran HAM).

Selanjutnya, antara nasionalisme negara dan etnik juga berbeda dalam memaknai pembangunan di Papua. Narasi dominan (nasionalis Indonesia) memaknai "pembangunan" sebagai upaya modernisasi orang Papua. Sebaliknya, narasi tandingan (nasionalis Papua) memaknai "pembangunan" sebagai migrasi tenaga kerja dari luar Papua (Jawa, Maluku, Nusa Tenggara, Bali, Sumatera, Sulawesi, dan wilayah lain Indonesia) dan marjinalisasi orang Papua. Dalam konteks disparitas ekonomi dan pembangunan antara Papua dengan daerah-daerah lain di Indonesia tidak terlepas dari adanya conflict of interest antara para pendatang di Papua, diskriminasi kebijakan pusat kepada daerah, dan ekspolitasi Sumber Daya Manusia (SDM) serta budaya Papua. Otonomi Khusus tidak secara otomatis menjamin terciptanya kesejahteraan dan pembangunan ekonomi untuk rakyat Papua. Pada akhirnya Otonomi Khusus yang sudah berjalan sekitar 17 tahun masih menimbulkan pro dan kontra antara Pemerintah Pusat (Jakarta) dan Papua (Jayapura), serta di antara penduduk Papua antara yang pro-otonomi dan menentang otonomi.

Sementara itu, jika dianalisis dari aspek aktor konflik (pelaku sosial) berdasar kepentingan politik yaitu perjuangan untuk mempertahankan Papua di dalam negara Indonesia atau sebaliknya memisahkan Papua dari negara Indonesia. Dalam konteks ini ada tiga kategori pelaku konflik yaitu: (1) kelompok-kelompok pro-kemerdekaan terdiri 
atas OPM, TPN, Satgas Papua, Dewan Revolusioner OPM, Kelompok Internasional ProKemerdekaan; (2) kelompok-kelompok pronegara Indonesia terdiri atas TNI, Polri, Barisan Merah Putih; dan (3) kelompok-kelompok tengah mencakup organisasi-organisasi sosial dan keagamaan dan media massa (Widjojo (ed.), 2009).

Sejak Otonomi Khusus Papua diberlakukan pada 2002, dalam bidang politik yang menguat adalah munculnya sentimen primordial, seperti putra daerah dan menguatnya identitas etnis menjadi keunggulan untuk meraih elektabilitas guna memenangi pertarungan pemilihan kepala daerah (Lefaan, 2018: 35; Nugroho, 2008: 91). Fenomena saat ini adalah makin menguatnya sentimen primordial atas dasar identitas etnis (Kepapuaan) dalam berbagai bidang kehidupan. Muncul pandangan yang tajam antara putra daerah (Papua) dan pendatang (nonPapua) dalam interaksi sosial di Papua. Otonomi daerah dimaknai secara sempit sebagai otonomi putra daerah. Hal yang tidak dapat dielakkan adalah meniadakan heterogen, karena sumbu kehidupan harus ditentukan oleh putra daerah sendiri. Dapat dikatakan bahwa pada masa otonomi, pemerintah daerah memiliki kekuasaan yang otonom, ikatan primordialisme kesukuan meningkat dan nyaris menghilangkan rasa kebangsaan. Hal ini tentu saja bisa menjadi ancaman bagi persatuan bangsa dan kehidupan yang harmonis dalam masyarakat yang heterogen. Praktik seperti itu juga memperlemah Keindonesiaan (nasionalisme negara), sehingga nasionalisme kini menjadi tema yang berat. Nasionalisme tergerus oleh primordialisme dan globalisasi dunia, artinya nasionalisme mengalami gempuran hebat, sehingga bangun Keindonesiaan terasa memudar dan kerap menjadi demikian lemah (Edy., Setyowati., \& Wasino, 2018: 64; Lindayanti \& Zaiyardam, 2015: 171).

Relasi Indonesia dan Papua yang dominan adalah ketidakharmonisan (Marit \& Warami, 2018: 41) dalam bentuk aksi demonstrasi dan konflik di beberapa kota di Papua, seperti di Jayapura, Sorong, Biak, Mimika, Nabire, Manokwari, dan beberapa wilayah di Pegunungan
Tengah. Konflik di Papua intensitasnya semakin meningkat, semakin meluas, dan semakin terbuka. Dimensi konflik di Papua cukup beragam yaitu antara Pemerintah Indonesia melawan gerakan pro-kemerdekaan (OPM), ketegangan antarsuku dan antara penduduk asli Papua dan penduduk non-Papua (pendatang). Ragam konflik biasanya tidak berdiri sendiri, namun saling bersinggungan antara faktor politik, ekonomi, dan sosial budaya (Lumintang, 2012: 69; Mambraku, 2015: 76; Senis, 2013: 39; Supriyono, 2014: 74; Trajano, 2010; 14). Sementara itu, secara teoretik konflik Papua dapat diklasifikasikan sebagai separatist conflict dan ethnopolitical conflict, karena ditandai oleh adanya tuntutan untuk merdeka dari negara Indonesia dan instrumentalisasi etnisitas untuk tujuan-tujuan politik (Heidbuchel 2007 dalam Widjojo (ed.), 2009: 20).

Konflik yang terjadi karena faktor politik (konflik politik) muncul dalam dua bentuk yaitu kekerasan politik dan konflik dalam pilkada (Marit \& Warami, 2018: 41; Widjojo (ed.), 2009: 12; Wonda, 2016: 113). Kekerasan politik adalah pengalaman objektif yang dialami oleh rakyat Papua sebagai akibat dari strategi utama Pemerintah Pusat untuk memerangi OPM. Periode 1962-1964 dapat dikatakan sebagai perang rahasia antara TNI dengan OPM. Representasi menonjol negara dan Pemerintah Pusat adalah aparat militer dan kepolisian, atau institusi negara hadir di Papua dalam bentuk kekuatan-kekuatan militer. Konteks politik Indonesia Orde Baru, kekerasan politik dijustifikasi sebagai tugas mulia TNI dalam mempertahankan negara Indonesia dengan semboyan "NKRI Harga Mati”.

Pengalaman orang Papua terhadap kekerasan politik menumbuhkan ingatan kolektif tentang penderitaan yang sering disebut dengan memoria passionis. Memoria passionis adalah suatu ingatan (kenangan) masa lalu yang tidak bisa lupa dari ranah kehidupannya karena suatu pengalaman peristiwa yang menyakitkan baik fisik maupun psikis dan ceritanya akan dikenang oleh generasi ke generasi berikutnya. Memoria passionis mengacu pada kenangan akan trauma akibat kekerasan terbuka dan marjinalisasi sosial 
dan ekonomi secara umum (Suryawan, 2012: 144).

Konflik antara OPM dan Indonesia terjadi karena ada perbedaan tajam antara nasionalis Indonesia dan nasionalis Papua dalam memaknai "integrasi" Papua ke negara Indonesia, Widjojo (ed.) (2009: 10-11) menarik simpulan sebagai berikut.

"Historiografi dan status politik Papua haruslah dilihat sebagai hasil pertarungan politik antara Indonesia dan Belanda di mana rakyat Papua tidak dilibatkan di dalamnya. Selain itu juga harus dipandang dalam konteksnya yaitu masa perang dingin dimana Amerika Serikat berusaha membendung pengaruh Uni Soviet melalui dukungannya terhadap integrasi Papua ke Indonesia. Sebagai implikasinya, penulisan narasi besar yakni sejarah integrasi Papua dan pendefinisian status politik Papua, yang didominasi para nasionalis Indonesia, tidak memberikan ruang bagi nasionalisme Papua sebagai antitesis dari nasionalisme Indonesia. Namun, yang harus menjadi catatan adalah bahwa konstruksi nasionalisme Papua ini telah dibentuk pada masa kolonial Belanda yang dapat saja ditujukan oleh Belanda untuk mengklaim perbedaan ras orang Papua dengan orang Indonesia dan mempertahankan Belanda di Tanah Papua”.

Tanah Papua juga memiliki potensi ketegangan (konflik) antarumat beragama khususnya antara umat Islam dan Kristen (Afwan, 2015: 13; Crisis Group Asia Briefing No 66, 19 Juli 2007; Crisis Group Asia Report No 154, 16 Juni 2008; Crisis Group Asia Report No 188, March 11, 2010). Penyebab utamanya yaitu: (1) perubahan demografis: perpindahan penduduk Muslim dari daerah lain di Indonesia ke Papua yang terus berlangsung; (2) munculnya kelompok-kelompok baru yang bersifat eksklusif di masyarakat Islam maupun Kristen yang telah memperkuat persepsi bahwa agama yang lain adalah musuh; (3) imbas dari konflik Maluku yang tidak hilang-hilang; dan (4) pengaruh dari perkembangan di luar Papua dan teknologi baru. Pemerintah daerah maupun pusat perlu memastikan bahwa tidak ada peraturan daerah yang diskriminatif yang dijadikan undangundang dan tidak ada kegiatan oleh organisasi agama yang eksklusif yang dibantu oleh dana pemerintah.

Aksi demonstrasi, kekerasan, teror, dan konflik di Papua (Jayapura) intensitasnya cukup tinggi terutama menjelang, pada saat dan setelah 1 Desember setiap tahun yang diklaim oleh sekelompok masyarakat Papua sebagai hari kemerdekaan Papua. Khusus yang terjadi di Jayapura hal ini karena Jayapura sebagai pusat perekonomian, pendidikan, kebudayaan, pemerintahan dan aktivitas politik di Tanah Papua.

Pada era reformasi dan Otonomi Khusus Papua ketegangan dan konflik baik vertikal maupun horizontal masih terjadi di Papua. Narasi dominan (nasionalis Indonesia) bahwa "Otonomi Khusus" diletakkan dalam konteks integrasi nasional dan pembangunan (Iry, 2009: 19; Reumi, 2015: 102; Wonda, 2016: 113). Sebaliknya, narasi tandingan (nasionalis Papua) bahwa "Otsus" sebagai pelurusan sejarah Papua, perlindungan hak-hak orang Papua, pembangunan untuk orang Papua dan repapuanisasi. Pada konteks pengalaman orang Papua, marjinalisasi dapat dilihat pada aspek demografi, ekonomi, dan politik. Pada bidang-bidang tersebut penduduk asli Papua kalah dominan peranannya dibandingkan penduduk non-Papua (pendatang), kecuali untuk saat ini di bidang politik (pemerintahan) penduduk asli Papua mendominasi dibandingkan pendatang.

Nasionalisme etnik Papua tetap tumbuh dan berkembang dengan karakteristik (keunikan) yang berbeda dengan etno-nasionalisme lain di Indonesia. Namun dalam jangka panjang nasionalisme etnik menyatu dalam nasionalime kewarganegaraan. Penguatan civic nasionalisme di Papua harus ditumbuhkembangkan. Semangat merawat toleransi sesama anak bangsa (khususnya generasi muda) harus dikedepankan (Jati, (ed.), 2017: 25-26; Zuhdi, 2017: 38-39). Setiap warga negara harus menjunjung tinggi perbedaan dan keragaman serta mengeliminasi perbedaan sebagai sumber pertentangan dan konflik yang akan merusak konstruksi Keindonesiaan. 


\section{SIMPULAN}

Dinamika pertumbuhan dan perkembangan ethnic nasionalisme Papua sejak integrasi Papua ke Indonesia hingga era reformasi dipengaruhi oleh kebijakan Pemerintah Pusat (Jakarta). Menguatnya nasionalisme etnik Papua karena kebijakan pemerintah yang tidak diterima sepenuhnya oleh orang asli Papua (OAP). OAP merasa dimarginalisasi dan didiskriminasi dalam proses pembangunan baik aspek politik, ekonomi, sosial dan budaya khususnya di masa Orde Baru. Nasionalisme etnik Papua ditandai oleh adanya tuntutan untuk merdeka dari negara Indonesia dan digunakannya instrumentalisasi etnisitas untuk tujuan-tujuan politik. Nasionalisme etnik akhirnya menggeser kewarganegaraan dan atau negara nasionalisme sebagai bagian dari negara Indonesia. Dalam jangka panjang nasionalisme etnik dapat berkembang menjadi nasionalime kewarganegaraan. Penguatan civic nasionalisme harus ditumbuhkembangkan khususnya pada generasi muda Papua (pelajar dan mahasiswa). Setiap warga negara Indonesia di Tanah Papua harus menjunjung tinggi perbedaan dan keragaman serta mengeliminir perbedaan sebagai sumber pertentangan dan konflik yang akan merusak konstruksi dan narasi nasionalisme kewarganegaraan.

\section{REFERENSI}

Abdullah, T. (2001). Nasionalisme \& Sejarah. Bandung: CV. Satya Historika.

Aditjondro, G. J. (2000). Cahaya Bintang Kejora: Papua Barat dalam Kajian Sejarah, Budaya, Ekonomi, dan Hak Asasi Manusia. Jakarta: Elsam.

Afwan, B. A. (2015). Mutiara Terpendam Papua: Potensi Kearifan Lokal untuk Perdamaian di Tanah Papua. Yogyakarta: Sekolah Pascasarjana UGM.

Amboro, K. (2015). "Membangun Kesadaran Berawal Dari Pemahaman: Relasi Pemahaman Sejarah Dengan Kesadaran Sejarah Mahasiswa Program Studi Pendidikan Sejarah FKIP Universitas
Muhammadiyah Metro. Jurnal Historia, 3(2): 109-118.

Andriana, N. (Ed.). (2016). Nasionalisme dan Keindonesiaan di Perbatasan. Yogyakarta: Calpulis - LIPI.

Creswell, J. W. (2014). Research Design: Pendekatan Kualitatif, Kuantitatif, dan Mixed. Yogyakarta: Pustaka Pelajar.

Crisis Group Asia Briefing No 66, 19 Juli 2007. Papua: Perspektif Lokal atas Konflik. Jakarta/Brussels: International Crisis Group.

Crisis Group Asia Report No 154, 16 Juni 2008. Indonesia: Ketegangan Antar Agama di Papua. Jakarta/Brussels: International Crisis Group.

Crisis Group Asia Report No 188, March 11, 2010. Radicalisation and Dialogue in Papua. Jakarta/Brussels: International Crisis Group.

Edy, A, N., Setyowati, D, L., \& Wasino, 2018. "Implementation of Character Education through Nationality Historical Learning in SMK Negeri Karangdadap Pekalongan Regency”. Journal of Educational Social Studies (JESS), 7(1): 61-66.

Hardiansyah, A. (2013). "Teori Pengetahuan Edmund Husserl”. Jurnal Substantia. Vol. 15(2): 228-238.

Hasbiansyah (2008). "Pendekatan Fenomenologi: Pengantar Praktik Penelitian dalam Ilmu Sosial dan Komunikasi”. Jurnal Mediator, 9(1):163-180.

Iry, A. G. (2009). Dari Papua Meneropong Indonesia: Darah Mengalir di Bumi Cenderawasih. Jakarta: Grasindo.

Jailani, M. S. (2013). "Ragam Penelitian Qualitative (Ethnografi, Fenomenologi, Grounded Theory dan Studi Kasus)". Jurnal Edu-Bio, 4: 41-50.

Jati, W. R. (Ed.). (2017). Relasi Nasionalisme dan Globalisasi Kontemporer: Sebuah Kajian Konseptual. Yogyakarta: Pustaka Pelajar LIPI.

Kaisiepo, M. (1999). "Ke-Irian-an dan KeIndonesia-an: Mengkaji Nasionalisme dalam Konteks Lokal", dalam Palit, D.I, 
(Ed.), Dinamika Nasionalisme Indonesia. Salatiga: Yayasan Bina Darma.

Kartodirdjo, S. (1994). Pembangunan Bangsa tentang Nasionalisme, Kesadaran dan Kebudayaan Nasional. Yogyakarta: Aditya Media.

Larasati, C. E. (2014). "Representasi Identitas Etnis Papua Dalam Film Lost In Papua”. Jurnal Commonline Departemen Komunikasi, 3 (3): 488-497.

Lefaan, A. (2018). "Mengantisipasi Politik Representasi Menjelang Pilkada 2018 Di Papua (Fenomena Politik Dari Masa ke Masa yang Tidak Pernah Pupus)". Jurnal Ilmu Sosial, 16(1): 35-40.

Lindayanti \& Zaiyardam, (2015). "Konflik dan Integrasi Dalam Masyarakat Plural: Jambi 1979-2012". Jurnal Paramita, 25(2): 169184.

Lumintang, O. M. (2012). “Konflik Tanah Di Arso Papua 1980-2002”. Jurnal Paramita, 22 (1): 69-80.

Mahfud, C. (2014). Pendidikan Multikultural. Yogyakarta: Pustaka Pelajar.

Mambraku, N. S. (2015). "Penyelesaian Konflik di Tanah Papua Dalam Perspektif Politik”. Jurnal Kajian, 20 (2): 75-85.

Marit, E, L., \& Warami, H. (2018). “Wacana 'Papua Tanah Damai' Dalam Bingkai Otonomi Khusus Papua”. Jurnal Ilmu Sosial, 16 (1): 41-46.

Meteray, B. (2012). Nasionalisme Ganda Orang Papua, Jakarta: PT. Kompas Media Nusantara.

Narwaya, St, T, G., Faruk, H, T. \& Budiawan, (2018). "Politik Negosiasi Diskursus Rekonsiliasi 1965 Dan Imaji Keindonesiaan Pasca-Orde Baru". Jurnal Politik Profetik, 6(1): 54-74.

Novianti, D., \& Tripambudi, S. (2014). " "Studi Fenomenologi: Tumbuhnya Prasangka etnis di Yogyakarta”. Jurnal Ilmu Komunikasi, 12 (2): 119-135.

Nugroho, R, (2008). Pendidikan Indonesia: Harapan, Visi, dan Strategi. Yogyakarta: Pustaka Pelajar.
Pamungkas, C. (2016). "Nationalism of Border Society: Case Study of Sangir People, Sangihe Regency”. Journal Komunitas, 8(1): 59-72.

Pujiriyani, D. W. (2013). "Re-Imajinasi KeIndonesiaan Dalam Konteks "Network Society". Jurnal Komunitas, 5 (2): 151-161.

Rachman, M. (2015). 5 Pendekatan Penelitian. Yogyakarta: Magnum Pustaka Utama.

Rahab, A. (2006). "Operasi-Operasi Militer di Papua: Pagar Makan Tanaman?”. Jurnal Penelitian Politik, 3 (1): 3-23.

Reumi, F. (2015). "Semangat Otonomi Khusus dan Sistem Federal Dalam Mempertahankan NKRI". Jurnal Hukum dan Masyarakat, 14 (2): 100-129.

Samego (2008). Menumbuhkan (Kembali) Nasionalisme Melalui Nilai-Nilai Kearifan Lokal. Jakarta: Sekretariat Negara Republik Indonesia.

Senis, Y. (2013). "Globalisasi dan Kemiskinan Di Papua Dalam Perspektif Gramsci”. Jurnal Dinamika Sosial, 1 (1): 39-48.

Soedharto, (1995). Sejarah Perjuangan Bangsa Indonesia di Irian Jaya. Jayapura: DHD-45 Provinsi Irian Jaya dan BP-7 Provinsi Irian Jaya.

Supriyono, J. (2014). "Diskursus Kolonialistik dalam Pembangunan di Papua: Orang Papua dalam Pandangan Negara". Jurnal Ultima Humaniora, (2) 1: 59-78.

Surakhmad, W. (2009). Pendidikan Nasional Strategi dan Tragedi, Jakarta: PT Kompas Media Nusantara.

Suryadi, A., Hayat, B., Rustana, C., \& Abduhzen, M. (2014). Pendidikan untuk Transformasi Bangsa: Arah Baru Pendidikan untuk Perubahan Mental Bangsa. Jakarta: PT. Kompas Media Nusantara.

Suryawan, I. Ng. (2012). "Dari Memoria Passionis Ke Foreri: Sejarah Politik Papua 19992000”. Jurnal Paramita, 22 (2): 143-156.

Trajano, J.C.I. L. (2010). "Ethnic Nationalisme and Separatism in West Papua, Indonesia". Journal of Peace, Conflict and Development, Issue 16: 12-35.

Widjojo, M. S. (Ed.). 2009. Papua Road Map: Negotiating the Past, Improve the Present 
and Securing the Future. Jakarta: LIPI Yayasan Tifa - Yayasan Obor Indonesia.

Wonda, Y. (2016). "Responsitif Kebijakan Pemerintah Terhadap Dinamika Perjuangan Organisasi Papua Merdeka (OPM) Di Kabupaten Puncak Jaya”. Jurnal Ekologi Birokrasi, 2 (1): 108-121.

Zuhdi, S. (2017). Integrasi Bangsa Dalam Bingkai Keindonesiaan. Jakarta: Wedatama Widya Sastra. 